\title{
Typing of inflammatory lesions of the pituitary
}

\author{
J. Warmbier ${ }^{1}$ - D. K. Lüdecke ${ }^{2}$. J. Flitsch ${ }^{2} \cdot$ M. Buchfelder ${ }^{3} \cdot$ R. Fahlbusch ${ }^{4} \cdot$ U. J. Knappe ${ }^{5} \cdot$ J. Kreutzer $^{6} \cdot$ R. Buslei $^{7}$. \\ M. Bergmann ${ }^{8} \cdot$ F. Heppner ${ }^{9} \cdot$ M. Glatzel $^{1} \cdot$ W. Saeger ${ }^{1,10}$
}

Accepted: 19 August 2021 / Published online: 31 August 2021

(c) The Author(s) 2021

\begin{abstract}
Inflammatory pituitary lesions account for $1.8 \%$ of all specimens from the German Pituitary Tumor Registry. They occure in $0.5 \%$ of the autoptical specimens and in $2.2 \%$ of the surgical cases. Women are significantly more often affected than men and are often younger when first diagnosed. In general, primary and secondary inflammation can be distinguished, with secondary types occurring more frequently $(75.1 \%)$ than idiopathic inflammatory lesions (15.4\%). In primary inflammation, the lymphocytic type is more common (88.5\%) than the granulomatous type of hypophysitis (11.5\%). The most common causes of secondary inflammation are Rathke's cleft cysts (48.6\%), followed by tumors (17.4\%) such as the craniopharyngioma $(9.1 \%)$, adenoma $(5.5 \%)$ or germinoma (2.0\%). More causes are tumor-like lesions $(7.1 \%)$ such as xanthogranuloma (3.5\%) or Langerhans histiocytosis (3.5\%), abscesses (5.5\%), generalized infections (5.1\%), spreaded inflammations $(4.7 \%)$ and previous surgeries $(4.0 \%)$. In $1.6 \%$ of all specimens the reason for the inflammation remains unclear. The described classification of hypophysitis is important for specific treatment planning after surgery.
\end{abstract}

Keyword Pituitary $\cdot$ Hypophysitis $\cdot$ Pathology $\cdot$ Classification

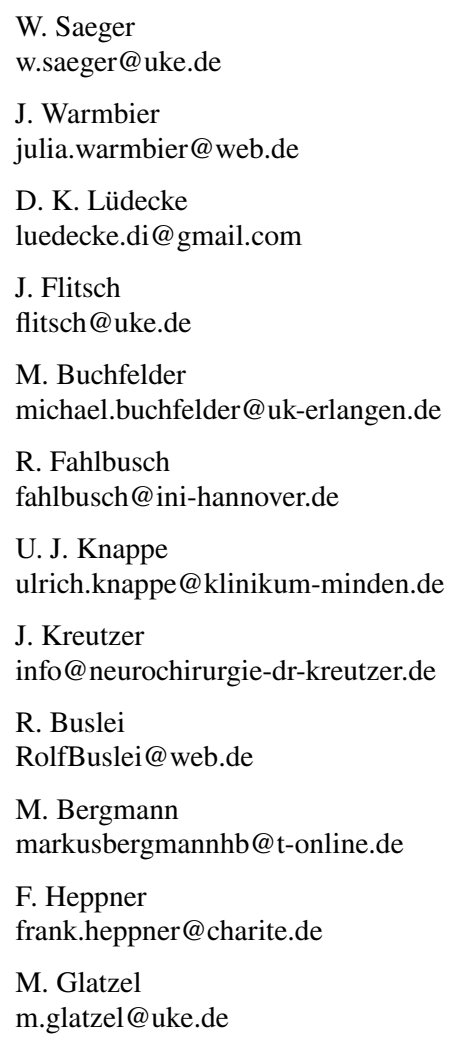

Institute of Neuropathology of the University of Hamburg, UKE, 20246 Hamburg, Germany

2 Clinic of Neurosurgery of the University of Hamburg, UKE, 20246 Hamburg, Germany

3 Clinic of Neurosurgery, Friedrich-Alexander University Erlangen-Nürnberg (FAU), 91054 Erlangen, Germany

4 International Neuroscience Institute (INI), Rudolf-Pichelmayr-Str. 4, 30625 Hannover, Germany

5 Department of Neurosurgery, Johannes-Wesling-Klinikum Minden, Ruhr-University Bochum (RUB), 32429 Minden, Germany

6 Praxis for Neurosurgery, 90941 Nuremberg, Germany

7 Institute of Pathology, SozialStiftung Bamberg, 96049 Bamberg, Germany

8 Institute of Neuropathology, Klinikum Bremen-Mitte, 28205 Bremen, Germany

9 Institute of Neuropathology of the Humboldt University of Berlin, Charitè, 10117 Berlin, Germany

10 Institutes of Pathology and Neuropathology of the University of Hamburg, UKE, Martinistraße 52, 20246 Hamburg, Germany 


\section{Introduction}

Inflammatory findings in the pituitary gland represent a rare differential diagnosis to neoplastic lesions of the sellar region. Since clinical symptoms, radiological imaging (Fig. 1) and sometimes even histological findings are often non-specific, a precise diagnosis can be difficult and only be done by comparisons of radiology, pathology and clinical data [1]. Small accumulations of lymphocytes-occasionally detected in the pituitary intermediate zone-should not be taken into account as they are not an expression of inflammation, but rather represent residues of lymphoid tissue from the craniopharyngeal duct [2]. Primary idiopathic hypophysitis is to be differentiated from secondary types such as inflammatory lesions due to Rathke cleft cysts, craniopharyngeomas or germinomas or involvement of the pituitary in generalized inflammation (e.g. sarcoidosis, IgG4-related disease) [3].

An autoimmune genesis is assumed in primary hypophysitis, but so far no antipituitary antibodies have been determined whose specificity and sensitivity are high enough to allow an accurate diagnosis [4]. Future research remains necessary for further categorizing autoimmune hypophysitis [5]. Recently an inflammatory type was described that develops from autoimmunity against the transcription factor PIT-1 [6].

Some classifications published in the literature [3-5, 7-10] present other principles, differentiating primary hypophysitis by the cellular type of inflammation. Some only describe lymphocytic and granulomatous hypophysitis as primary lesions [3], others define also xanthomatous hypophysitis as primary [7, 9], and some also include IgG4-associated hypophysitis and necrotizing hypophysitis as primary inflammations $[4,5,10]$. Furthermore, mixed types such as

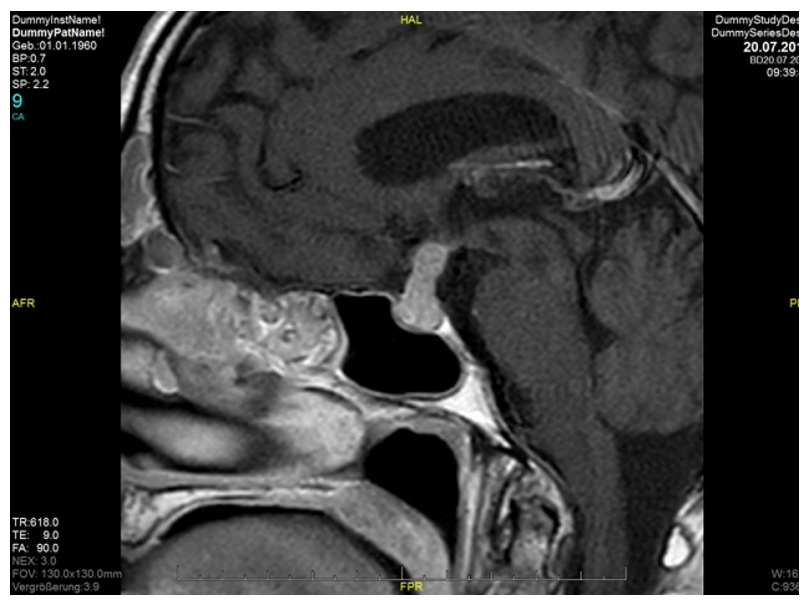

xanthogranulomatous hypophysitis and drug-induced hypophysitis (due to immune checkpoint inhibitors) can be found as independent entities in classifications [8].

The aim of our study was to propose a pathogenetic classification based on our very large collection of specimens in the German Registry of Pituitary Tumors that contains not only tumorous but also inflammatory pseudo-tumorous lesions. On the one hand, the focus was on emphasizing the importance of differentiating the various types of lesions, on the other hand, to point out the importance of IgG4-associated inflammation in this context. Since the study is retrospective, many nowadays necessary clinical data could not be included in contrast to prospective studies with smaller number of cases. However, we would like to emphasize the large number of patients in our study, as we are not aware of any other study on this topic that has included so many cases. The collection of Caturegli et al. [7] comprehends 379 patients but based on metastudies partly without histopathology. Therefore, this publication is not completely comparable with our collection.

\section{Material and methods}

For our studies, the collective was extracted from the files of the personal collection of one of the authors (WS) of the years 1970 to 1995 and the data from the German Pituitary Tumor Registry of the German Society for Endocrinology since its beginning in 1995 up to 2018. In the following the cases from 1970 to 2018 are summarized under the term of German Pituitary Tumor Registry.

Specimens had been embedded in paraffin. Sections were stained with hematoxylin-eosin and PAS and immunostained for pituitary hormones. Special cases were also immunostained for differentiating inflammatory infiltrates (CD3, CD5, CD20, CD45, CD68. IgG4, CD138, CD1a).

All cases with inflammatory infiltrates described in the histological reports were extracted from the database and sorted according to their diagnosis. If the diagnosis was inconclusive, clinical files were requested and examined for further indications regarding the diagnosis, such as subsequent tests, specific clinical symptoms or recurrences with new findings.

It should also be emphasized that according to Casanueva et al. a close collaboration between pathologists, endocrinologists, neurosurgeons and radiologists defines the criteria for a pituitary tumor center of excellence (PTCOE) [11]. Such cooperation formed the basis for the diagnoses and thus for the typing presented.

Fig. 1 MRI image of typical lymphocytic hypopyhsitis with stalk involvement 


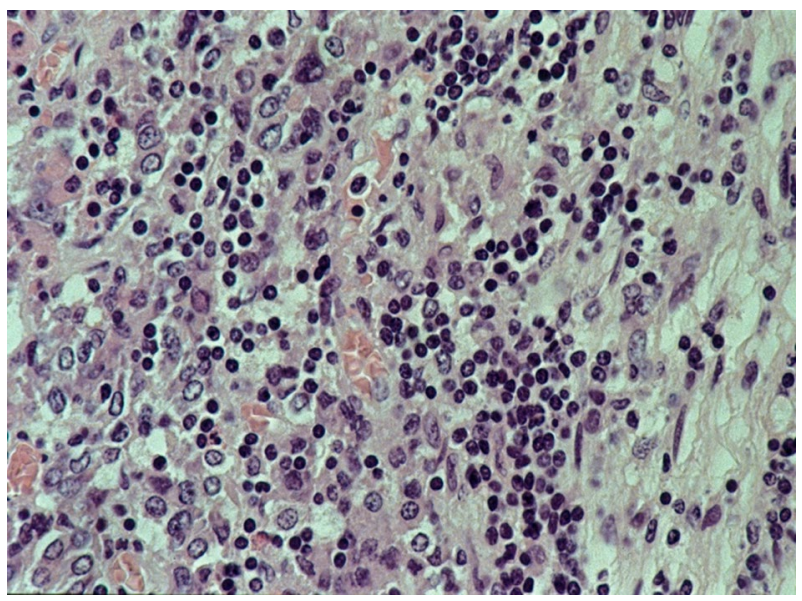

Fig. 2 Lymphocytic hypophysitis: partly focal, partly diffuse lymphocytic infiltration of the anterior lobe. HE staining, magnification $\times 400$

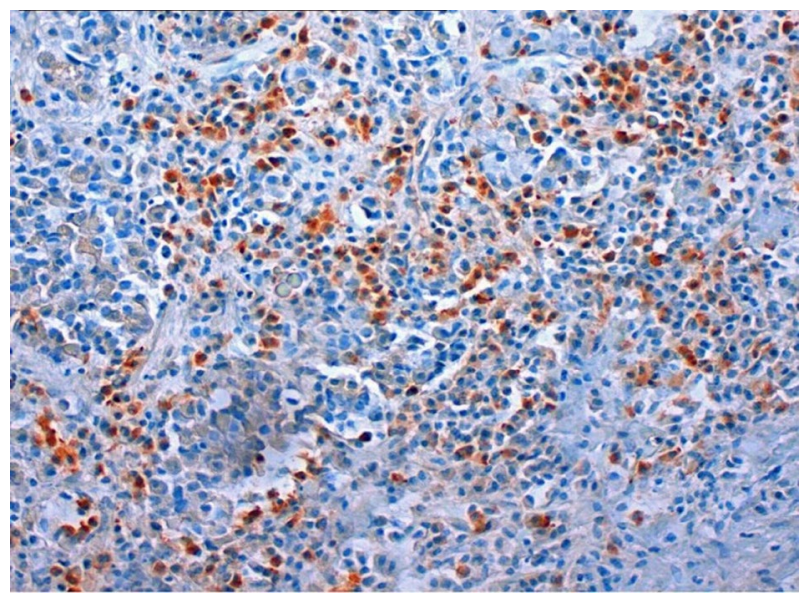

Fig. 3 Lymphocytic hypophysitis of IgG4-type: many IgG4-positive lymphocytes. IgG4-immunostaining, magnification $\times 250$

\section{Histological criteria for different inflammatory types}

We used the following criteria as indicators of inflammation: lympho-plasmacellular infiltrates of varying density (Fig. 2), granulocytes, granulation tissue, fibroses, scars with slight inflammatory infiltrates, IgG4-positivity in plasma cells (Fig. 3) and serum IgG4 levels.

The type and extent of the cellular infiltrate determined our diagnosis. A diffuse distribution pattern of the infiltrating lymphocytes and plasmocytes suggests an autoimmune primary hypophysitis, a more focal pattern for a secondary origin. If predominantly lymphocytic infiltrates are present, primary inflammation can be assumed; mixed-cell infiltrates consisting of lymphocytes, plasma cells, granulocytes, and histiocytes indicate secondary hypophysitis.

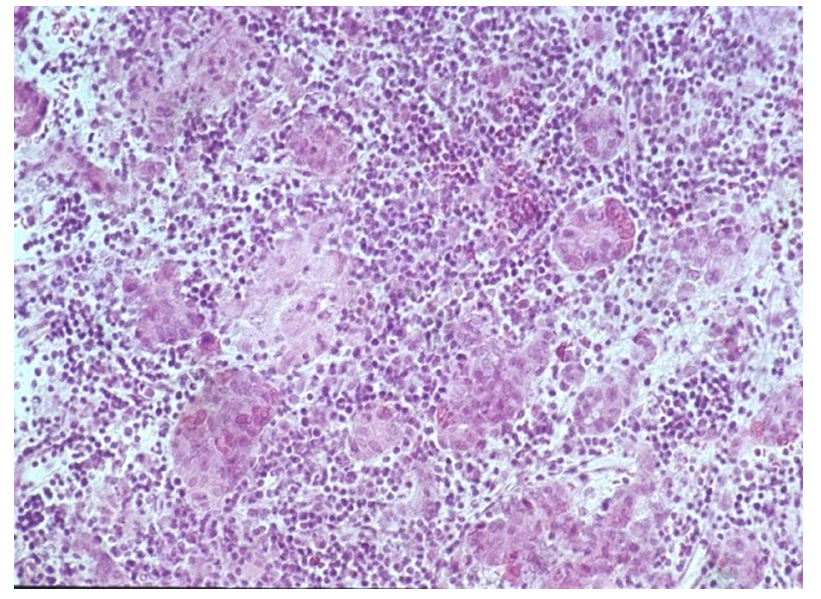

Fig. 4 Granulomatous hypophysitis: lymphocytic infiltration of the anterior lobe and granulomas with epitheloid cells and giant cells. HE staining, magnification $\times 250$

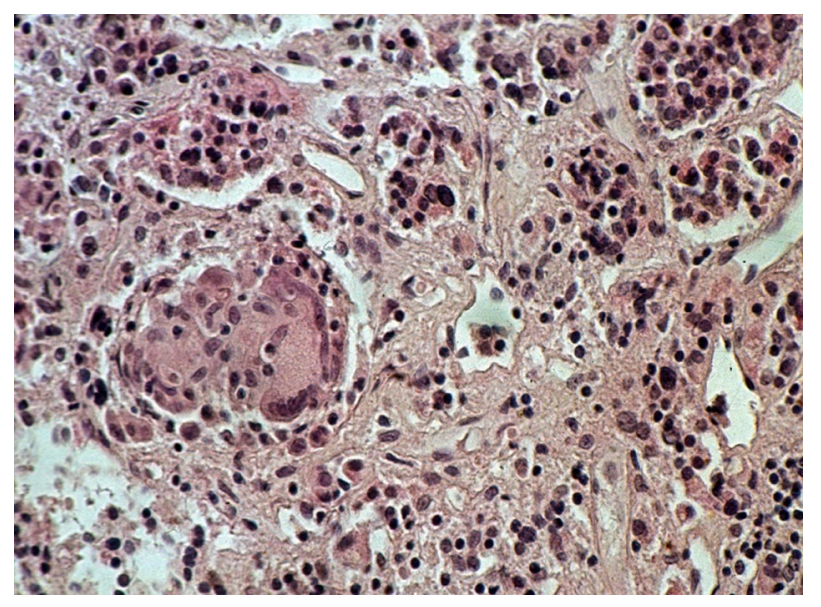

Fig. 5 Granulomatous hypophysitis: granulomas with multinucleated giant cells and sparse lymphocytic infiltration. HE staining, magnification $\times 440$

A dense lymphoplasmacytic infiltrate with a percentage of IgG4-positive of all IgG-positive cells exceeding $40 \%$ and absolute numbers of IgG4-positive plasma cells exceeding at least 10 per high power field (HPF) (Fig. 3), accompanied by a fibrosis and obliterative phlebitis suggest the diagnosis of an IgG4-related disease [12].

If a secondary inflammation could not be ruled out with certainty, or if the lymphocytic distribution was unusual, these cases were classified as probably primary lymphocytic hypophysitis. The diagnosis of definitely primary granulomatous hypophysitis (Figs. 4 and 5) can only be made if a generalized granulomatous infection, such as sarcoidosis or tuberculosis, has been ruled out [3]. This always requires reliable clinical information. If these were not available, then those patient cases were assigned to the category of probably 
Table 1 Hypophysitis gender comparison

\begin{tabular}{lllll}
\hline & Amount & $\begin{array}{l}\text { Average age at presentation } \\
\text { (years, mean } \pm \text { SD) }\end{array}$ & $\begin{array}{l}\text { Minimum age at pres- } \\
\text { entation (years) }\end{array}$ & $\begin{array}{l}\text { Maximum age } \\
\text { at presentation } \\
\text { (years) }\end{array}$ \\
\hline Women & 225 & $38.9 \pm 18.1$ & 0 & 89 \\
Men & 112 & $42.2 \pm 19.9$ & 4 & 98 \\
Total & 337 & $40.0 \pm 18.8$ & 0 & 98 \\
\hline
\end{tabular}

Table 2 Hypophysitis classification I

\begin{tabular}{llllll}
\hline & $\begin{array}{l}\text { Certainly } \\
\text { primary hypo- } \\
\text { phyitis }\end{array}$ & $\begin{array}{l}\text { Probably } \\
\text { primary hypo- } \\
\text { physitis }\end{array}$ & $\begin{array}{l}\text { Certainly second- } \\
\text { ary hypophysitis }\end{array}$ & $\begin{array}{l}\text { Probably second- } \\
\text { ary hypophysitis }\end{array}$ & Not clear \\
\hline Amount & 52 & 18 & 253 & 7 & 7 \\
$\%$ of hypophysitis & 15.4 & 5.3 & 75.1 & 2.1 & 2.1 \\
$\%$ in total & 0.28 & 0.1 & 1.38 & 0.04 & 0.04 \\
\hline
\end{tabular}

primary granulomatous hypophysitis. It should be noted that cases were also reported in which lymphocytic hypophysitis cannot be reliably differentiated from granulomatous hypophysitis [13].

The inflammations caused by another lesion were grouped under the category of secondary hypophysitis and subdivided according to their causal lesion. The difference between a hematogenously spreaded inflammation and a hypophysitis due to generalized inflammation hereby is that the hematogenous form originated from a former sepsis without any other active foci at this point.

If there was a case that could no longer be reliably assessed and also showed another lesion nearby, or if there was an atypical lesion that was structurally similar to a secondary inflammation, these were classified as likely secondary inflammation. If there was an uncharacteristic inflammatory lesion for which no evidence of a primary or secondary etiology was found, or if the specimens were insufficient or surrounding non-inflammatory tissue was lacking a clear diagnosis was not possible, these cases were classified as unclear hypophysitis.

In our collection, there was no case of drug-induced hypophysitis. This is why this category is not reflected in our classification. Nevertheless, it should be emphasized that this form of disease caused by checkpoint inhibitors is nowadays to be regarded as an important differential diagnosis [14].

\section{Results}

From 1970 to 201818,329 cases were collected in the Pituitary Tumor Registry. Inflammatory pituitary masses were histologically detected in $1.8 \%(\mathrm{n}=337)$ of all
Table 3 Primary hypophysitis

\begin{tabular}{llll}
\hline & $\begin{array}{l}\text { Lymphocytic } \\
\text { hypophsitis }\end{array}$ & $\begin{array}{l}\text { Granulomatous } \\
\text { hypophysitis }\end{array}$ & Total \\
\hline Amount & $\mathrm{n}=46$ & $\mathrm{n}=6$ & $\mathrm{n}=52$ \\
$\%$ & $88.5 \%$ & $11.5 \%$ & $75.1 \%$ \\
Women & $\mathrm{n}=27$ & $\mathrm{n}=4$ & $\mathrm{n}=31(59.6 \%)$ \\
Men & $\mathrm{n}=19$ & $\mathrm{n}=2$ & $\mathrm{n}=21(40.4 \%)$ \\
\hline
\end{tabular}

specimens of the sellar region. They occurred for $0.5 \%$ of the autoptical specimens and for $2.2 \%$ of the surgical cases. Women were significantly more often affected by hypophysitis than men $(n=225$ vs. $n=112)$ and were often younger when first diagnosed (Table 1). Primary and secondary inflammation can be distinguished, with secondary types occurring more frequently (77.2\%) than idiopathic inflammatory lesions (20.7\%) (Table 2).

\section{Certainly primary hypophysitis}

\section{Lymphocytic and granulomatous hypophysitis}

52 patient cases are classified as certainly primary hypophysitis (15.4\% of all inflammatory diagnoses) (Fig. 2). Within these the lymphocytic form is significantly more common $(88.5 \%)$ than the granulomatous hypophysitis (11.5\%) (Figs. 4 and 5). 59.6\% of all patients with certainly primary hypophysitis are woman, $40.4 \%$ are men (Table 3 ). The average age of the patients with definitely primary lymphocytic hypophysitis is 43.8 years, the average age of women is 39.0 years and the one of men 50.7 years. 


\section{IgG4-related hypophysitis}

13 of 21 re-examined cases in our database $(61.9 \%)$ previously diagnosed as primary hypophysitis fulfill the criteria for IgG4-related disease (Fig. 3). The positive results occur in six male patients $(46.2 \%)$ and in seven female patients $(53.8 \%)$. The overall mean age is 48.0 years, that of women 43.4 years and that of men 53.3 years.

\section{Probably primary hypophysitis}

In the cases without clear diagnosis, but with probably primary nature of inflammation, the percentage of granulomatous inflammations $(2.7 \%)$ is the same as that of lymphocytic inflammations $(2.7 \%)$. The total number of these patient cases was 18 .

\section{Certainly secondary hypophysitis}

The diagnosis of definitely secondary hypophysitis could be determined in 253 cases (75.1\%). The causes of this inflammation are the following (Table 4).

\section{Cyst-induced inflammation}

Cyst-induced inflammation is diagnosed in 138 cases (40.9\%). Rathke`s cleft cysts are the most common type of cysts and the most common type for secondary inflammation (37.2\%) (Fig. 6). They occurred significantly more often in women.

\section{Spreaded inflammation and abcesses}

Twelve inflammatory lesions (3.6\%) were due to a spreaded inflammation,

Table 4 Secondary Hypophysitis

\begin{tabular}{lllr}
\hline & Amount & $\begin{array}{l}\text { \% in certainly } \\
\text { secondary hypo- } \\
\text { physitis }\end{array}$ & \% in total \\
\hline Cysts & 138 & 54.5 & 40.9 \\
Spreaded inflammations & 12 & 4.7 & 3.6 \\
Tumor-associtaed lesions & 44 & 17.1 & 13.1 \\
Tumor-like lesions & 18 & 7.1 & 5.3 \\
Generalized inflamma- & 13 & 5.1 & 3.9 \\
$\quad$ tions & 10 & 4.0 & 3.0 \\
Post-surgery & 14 & 5.5 & 4.2 \\
Abcesses & 4 & 1.6 & 1.2 \\
Not classified & 253 & 100 & 75.1 \\
Total & & &
\end{tabular}

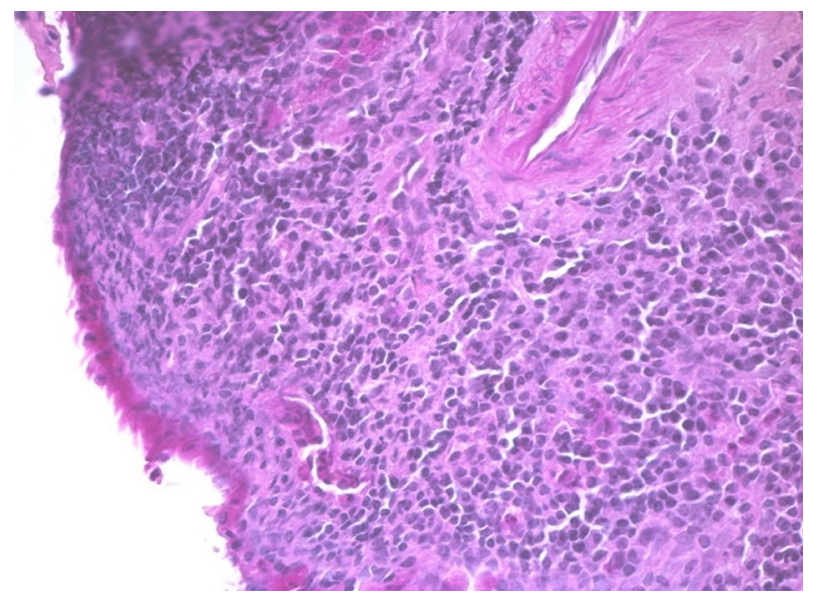

Fig. 6 Rathke's cleft cyst: lining of cubic and cylindrical epithelium partly with cilia, surrounded by lymphocytic infiltration. PAS staining, magnification $\times 250$

$4.2 \%(n=14)$ of the definitely secondary hypophysitis developed due to an abscess (Figs. 7 and 8), the cause of which could no longer be clearly determined.

\section{Tumor-induced hypophysitis}

$13.1 \%(n=44)$ of the patients developed hypophysitis due to a tumor. Craniopharyngiomas are the most likely tumorous lesions leading to inflammatory reactions of the pituitary (52.3\%), followed by adenoma (31.8\%) and germinoma (11.4\%) (Table 5) (Fig. 9). 60\% of the patients with germinoma were 12 years old or younger and the female to male ratio was 4:1.

In the group of adenomas the following subtypes were recorded: two gonadotrophic adenomas, one acidophilic

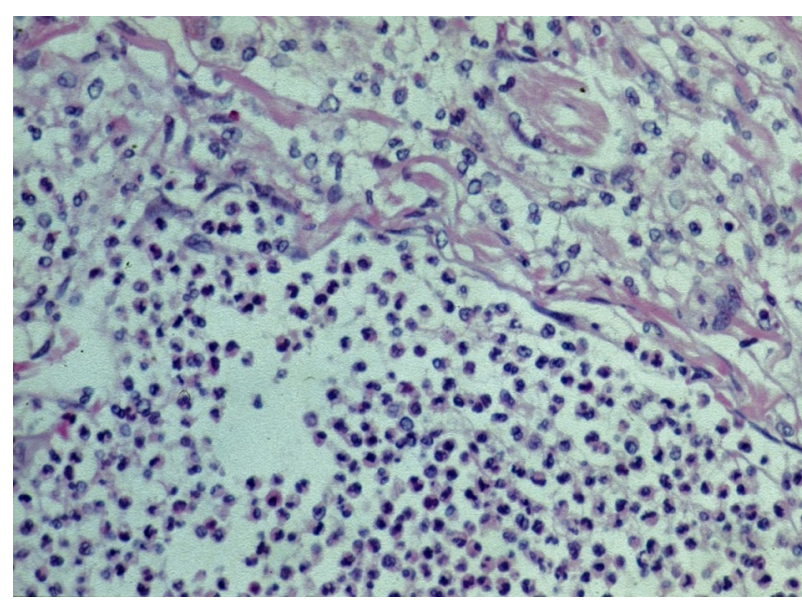

Fig. 7 Acute granulocytic inflammation as first stage of abscess surrounded by adenohypophysis with sparse inflammation, no fibrous tissue. PAS staining, magnification $\times 440$ 


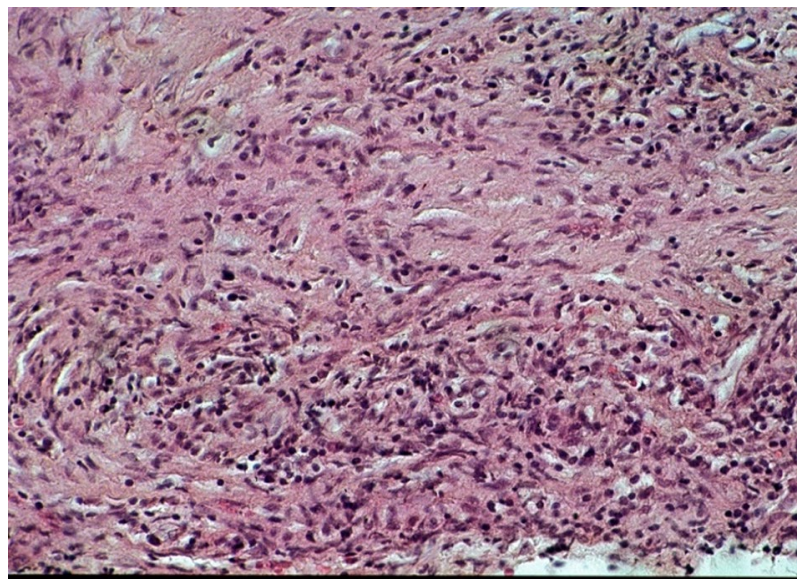

Fig. 8 Chronic inflammation with old fibrous abscess wall. HE staining, magnification $\times 250$

Table 5 Tumorous lesions stem cell adenoma (0.3\%), two ACTH cell adenomas $(0.6 \%)$, two null cell adenomas $(0.6 \%)$, five prolactin cell adenomas ( $1.5 \%)$, one mixed $\mathrm{GH} /$ prolactin cell adenoma $(0.3 \%)$ and one $\mathrm{GH}$ cell adenoma $(0.3 \%)$.

\section{Tumor-like lesions}

Xanthogranuloma or xanthomatous inflammation and Langerhans cell histiocytosis led to concomitant inflammation in 18 patients $(5.3 \%)$.

\section{Generalized inflammation}

$3.9 \%$ of all cases with inflammatory pituitary lesions have been due to generalized inflammations such as HIV/AIDS $(0.9 \%)$, tuberculosis $(1.2 \%)$, herpes simplex $(0.6 \%)$, sarcoidosis $(0.9 \%)$ or Crohn's disease $(0.3 \%)$ (Table 6$)$.

\begin{tabular}{|c|c|c|c|c|c|c|}
\hline & Germinoma & $\begin{array}{l}\text { Crani- } \\
\text { opharyn- } \\
\text { gioma }\end{array}$ & Adenoma & $\begin{array}{l}\text { Metastasis of squa- } \\
\text { mous cell carcinoma }\end{array}$ & $\begin{array}{l}\text { Spindle cell } \\
\text { oncocytoma }\end{array}$ & Total \\
\hline Amount & $\mathrm{n}=5$ & $\mathrm{n}=23$ & $\mathrm{n}=14$ & $\mathrm{n}=1$ & $\mathrm{n}=1$ & $\mathrm{n}=44$ \\
\hline $\begin{array}{l}\% \text { in tumor-asso- } \\
\text { ciated inflamma- } \\
\text { tions }\end{array}$ & $11.4 \%$ & $52.3 \%$ & $31.8 \%$ & $2.3 \%$ & $2.3 \%$ & $100 \%$ \\
\hline$\%$ in total & $1.5 \%$ & $6.8 \%$ & $4.2 \%$ & $0.3 \%$ & $0.3 \%$ & $13.2 \%$ \\
\hline
\end{tabular}

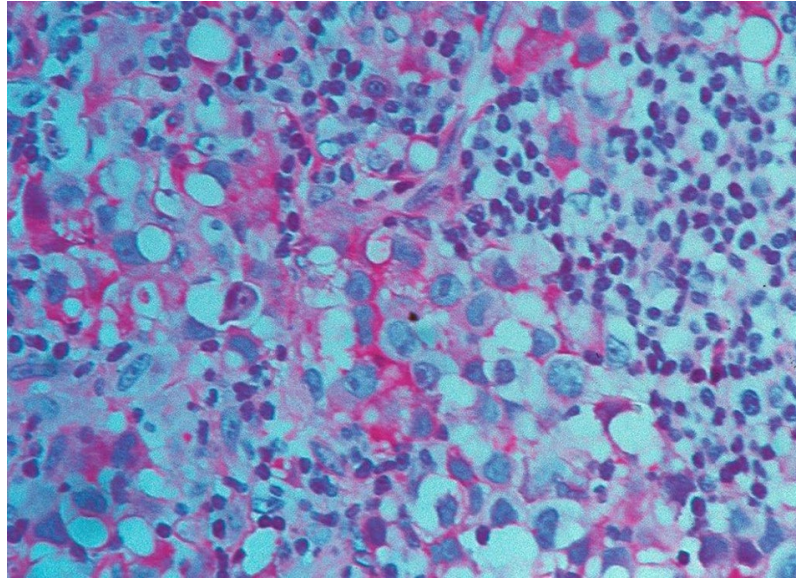

Fig. 9 Germinoma; lymphocytic infiltrates within the tumor tissue. PAS staining, magnification $\times 480$

\section{Pre-operation}

Inflammatory reactions due to a previous surgical procedure were present in $3.0 \%$ of the patient cases $(n=10)$.

\section{Not classified}

In $1.2 \%$ of all cases $(n=4)$ from this category, the cause of the secondary inflammation could not be reliably classified.

\section{Probably secondary hypophysitis}

Secondary hypophysitis was considered probable in seven cases $(2.1 \%)$, but a primary etiology could not be excluded with certainty. These cases included two that could not be further classified $(0.6 \%)$ and one each with a cyst, an abscess of unknown cause, locally extended inflammation,
Table 6 Generalized inflammations

\begin{tabular}{lllllll}
\hline & M. Crohn & Herpes simplex & AIDS & Sarcoidosis & Tuberculosis & In total \\
\hline Amount & $\mathrm{n}=1$ & $\mathrm{n}=2$ & $\mathrm{n}=3$ & $\mathrm{n}=3$ & $\mathrm{n}=4$ & 13 \\
$\%$ in total & 0.3 & 0.6 & 0.9 & 0.9 & 1.2 & 3.9 \\
\hline
\end{tabular}


tumor-associated inflammation, and a tumor-like lesion $(0.3 \%)$.

\section{Uncertain cases}

A clear classification of the inflammatory lesion was not possible in all these patients. There was a total of seven cases $(2.1 \%)$ in which the etiology of the inflammation could not be determined. In one case, the classification failed due to insufficient specimens $(0.3 \%)$. In the remaining six cases, no diagnosis could be made due to unclassifiable features (1.8\%).

\section{Discussion}

The differentiation of inflammatory and tumor-like lesions in the sellar region is very important for the patients. A clear understanding of the inflammation origin through the histopathological diagnosis offers different therapeutic approaches (Table 7).

Clinicopathologic studies on hypophysitis are published mostly in case reports or very small series. The paper of Tashiro et al. [15] comprehends 31 patients with very different endocrine diseases or pregnancies. To the best of our knowledge, our histopathologic collection of 337 cases of hypophysitis is the largest of all published series so far.

In a collection of surgical specimens patients suffered from primary hypophysitis in 0.38 to $1.1 \%$ of cases [16] whereas in our collection between 1970 and 2018, the diagnosis of certainly primary hypophysitis is made in $0.32 \%$ of surgical specimens and a probable primary hypophysitis in $0.11 \%$. Both groups together add up to $0.43 \%$, therefore the same range as published [16].

The IgG4-associated hypophysitis represents an important differential diagnosis of growing clinical interest. Inflammatory lesions previously suspected to occur as a primary local lesion could thus have been part of a generalized disease.

In our collection we found that in 13 of 29 cases an inflammation previously diagnosed as primary hypophysitis met the criteria for an IgG4-associated disease and the first diagnosis of idiopathic primary hypophysitis must be revised [12]. There were cases with the involvement of at least one other organ. The average age of patients was 62 years. If no other organs were known to be involved at the time of the histological diagnosis, the average age was 49 years [17-26].

Pituitary involvement in generalized $\mathrm{IgG} 4$-associated inflammation was very rare $(0-8 \%)$ in other studies [12, 27-31]. The number of IgG4-associated hypophysitis without further organ involvement was $65 \%$. This leads to

Table 7 Hypophysitis classification II

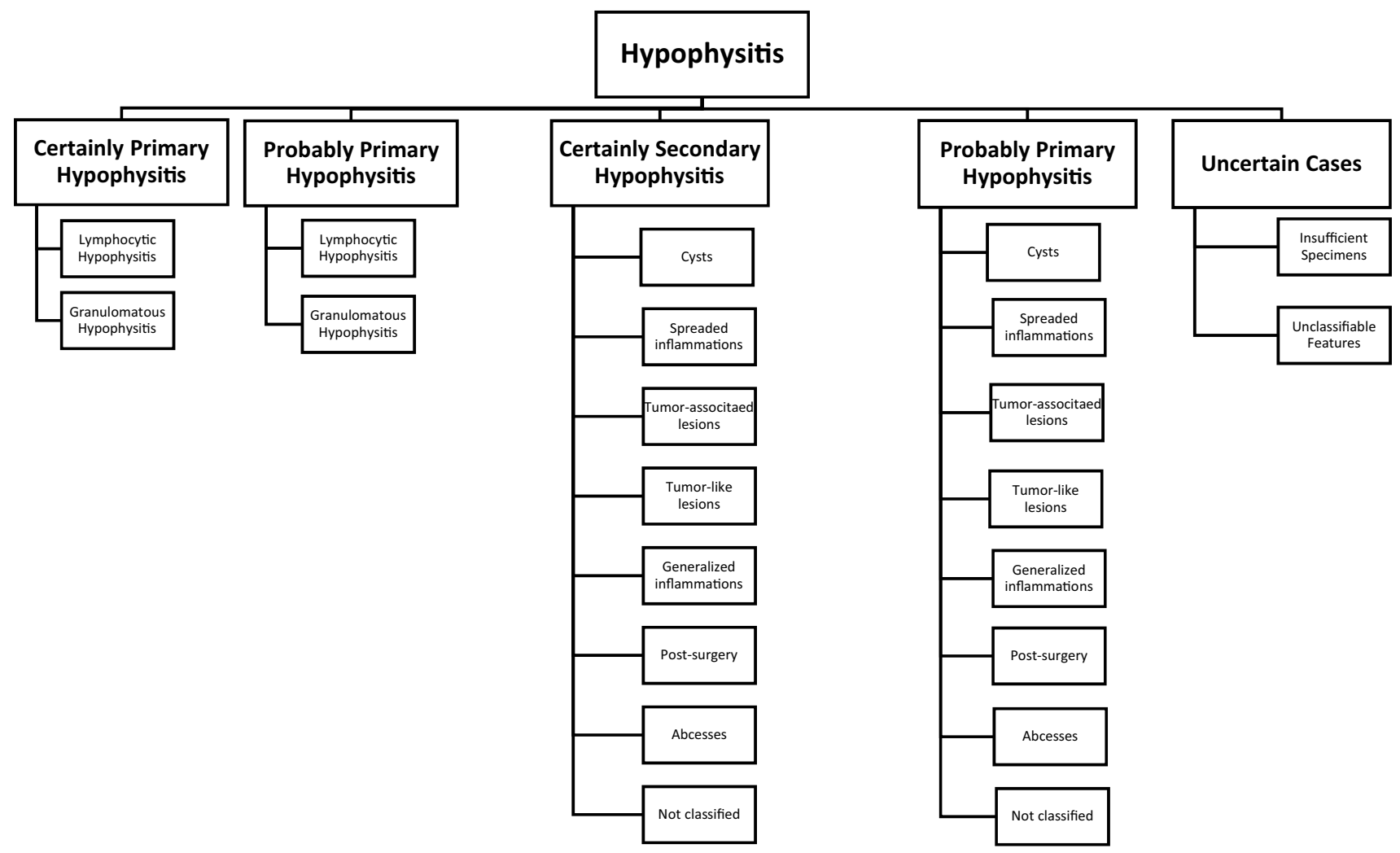


the assumption of a separate entity of hypophysitis independently of the generalized IgG4-associated inflammation [12].

From 2000 to 2018, 33 cases in our collective were tested for IgG4-positive plasma cells, of which 13 cases (39.4\%) tested positive. If we examine the entire group of primary hypophysitis $(\mathrm{N}=55)$ in the period from 2000 onwards, the percentage of IgG4-positivity is $23.6 \%$, with $61.8 \%$ of the cases with a primary form of inflammation not been tested for IgG4 -positive plasma cells.

Excluding the untested cases, the percentage of IgG4positive test results in previously diagnosed primary hypophysitis is $61.9 \%$. This frequency being significantly higher than previously published $[12,17,25]$, is probably related to the large number of untested cases, but it shows that IgG4associated hypophysitis is probably a frequent type of pituitary inflammation.

In our collective there is a slight predominance of female patients with IgG4-positive test results (53.8\%). The overall average age of 48 years is slightly below that reported by $\mathrm{Li}$ et al. published [32], whereby we also observe that men are on average older at diagnosis (53.3 years vs. 43.4 years).

Some authors suspect that granulomatous and lymphocytic hypophysitis are the same entity [15, 33-37]. One reason is the existence of structural similarities between the two forms of inflammation. Degranulated endocrine cells, focal oncocytic changes in the secretory cells and inflammatory cells within the periacinar membrane were detected in both lesions $[15,34,37]$. Since the occurrence of granulomatous hypophysitis is in some cases also accompanied by other autoimmune diseases, such as Hashimoto's thyroiditis, an autoimmune pathogenesis is also assumed. Honegger et al. describe an incidence of $22 \%$ for coexisting autoimmune diseases [35]. This thesis is also supported by the fact that in both lymphocytic and granulomatous hypophysitis contain immunoreactive antigens against macrophages in the cytoplasm of the giant cells [15, 34-37].

Secondary hypophysitis is an accompanying inflammation as a reaction to an evaluable lesion [1]. In our collective Rathke cleft cysts are the most common lesion causing secondary inflammation. Similar results were published by Teramoto et al. [38]. In $37.2 \%$ of all secondary inflammations based on Rathke's cleft cyst, in further $2.4 \%$ Rathke cleft cyst is assumed. The reason for the inflammatory reaction of the surrounding tissue in our opinion lies in leakage of cyst fluid due to disrupture of the cyst wall. In most studies on collectives of Rathke cysts, an excess of females was observed [39-41]. In our collective, the female proportion of patients with Rathke's cleft cysts is significantly higher than the male and is $74.8 \%$ in the group with a certain diagnosis. It could be proven that there was a connection between the severity of secondary hypophysitis and the occurrence of clinical symptoms, which reinforces the importance of diagnosing an inflammatory component in connection with Rathke cleft cysts [42].

Infections in other organs can be spreaded to the pituitary gland hematogenously or via nearby lesions [43, 44]. Abscesses can develop from pituitary lesions such as cysts and tumors. In $50 \%$ to $70 \%$ of all cases, no cause for the abscess development can be found [45]. Furthermore in about $50 \%$ of the cases the causative pathogenic microorganisms cannot be isolated [46]. In 1965 Montrieul et al. put forward the thesis that abscesses can also arise sterile through aseptic necrosis of pituitary tumors, since in some cases no bacterial populations could be detected in the abscess content [47]. Other authors believe that the "sterile" exudate is due to either inadequate bacterial tests for anaerobic microorganisms or previous antibiotic therapy [46, 48]. The incidence of pituitary abscesses is generally given as less than $1 \%(0.2-1 \%)$ of pituitary lesions [45]. The German Pituitary Tumor Registry comprises 18,329 cases. Of these, a pituitary abscess was diagnosed in 14 cases $(0.01 \%)$. Despite the low incidence rate, pituitary abscesses should be considered as a differential diagnosis, as the earlier figures make it clear that incorrect or missing therapy leads to a high mortality rate $[46,48-50]$.

Since Sautner et al. introduced the term of secondary hypophysitis [51], many cases of tumor-induced secondary hypophysitis have been described. Adenomas, craniopharyngiomas and germinomas, among others, can give rise to inflammation [10].

In our database, an adenoma is the cause of inflammation in $4.2 \%$ of all cases with hypophysitis. All types of adenoma occur, with prolactin adenomas being the most common (35.7\%). In 1983, Holck et al. discussed different causes for inflammations due to adenoma [52]. The original theories included the coincidental occurrence of two independent lesions, the triggering of inflammation by the adenoma through secretion of certain substances, or a reaction of the non-neoplastic tissue to the adenoma through compression or foreign body reaction. These theories are also described in more recent publications, although the adenoma antigens for inflammatory reaction could not yet be fully determined $[53,54]$. In 2020, Yamamoto et al. found out that one antigen being expressed by neoplasms is associated with pituitary diseases - the pituitary-specific transcription factor PIT-1 [6].

Adamantinomatous craniopharyngiomas are characterized by stratified squamous epithelium with a palisade-like basal cell layer and sometimes inflammatory infiltrations. Rathke cysts can also be lined by squamous epithelium, some of which also have keratinization. Necrosis of the squamous epithelium might trigger the inflammation. Infiltrates in the cyst walls have been described, especially in connection with relapses. In addition, typical craniopharyngioma findings such as calcifications, hemosiderin 
deposits and cholesterol crystals were observed in Rathke cysts which sometimes makes it difficult to distinguish them from each other.

Another pituitary neoplasm that can lead to inflammatory infiltrates is germinoma, which according to the WHO is the most common intra- and suprasellar germ cell tumor and occurs mainly in humans in the first two decades of life [55]. In our analysis, germinomas are present in $11.4 \%$ of tumor-associated inflammations. These occur in $60 \%$ of cases in prepubertal children. The diagnosis of a germinoma can be difficult because lymphocytic infiltrates are usually present in different amounts within this tumor [55]. Since these lymphocytes often infiltrate not only the tumor but also surrounding tissues and the number of lymphocytes may be very high, tumor cells cannot always clearly be identified in biopsies and the diagnosis of hypophysitis may be a pitfall $[56,57]$. It should be emphasized here that it is precisely the clinical symptoms and radiological changes that are present due to the inflammation that provide the first important clues in the diagnosis of a germinoma. Therefore, a germinoma diagnosis can only be made by combining histopathological, clinical and radiological findings.

Some authors define the xanthomatous hypophysitis as primary lesion [7, 9]. This assumption contradicts the observation that the inflammatory infiltrate occurs locally and the surrounding adenohypophysis appears unaffected [58, 59]. Nowadays, xanthogranulomatous hypophysitis is thought to be the result of inflammations and foreign body giant cells as reaction to necrotic squamous epithelia [60], and therefore we classified it as a secondary developed tumor-like lesion.

Generalized inflammatory diseases of other organs such as sarcoidosis, Wegener's disease, Crohn's disease and Sjögren's syndrome or generalized viral/bacterial infections can also affect the pituitary gland and trigger an inflammatory reaction [1]. Sarcoidosis is often undiagnosed during a lifetime. An autopsy on a large group revealed a sarcoid diagnosis in 43 people, with the disease ante-mortem only known in three cases [61]. A comparable observation was also described in a recent study with regard to neurosarcoidosis. The percentage of clinically diagnosed neurosarcoidosis (5-13\%) was below that of post-mortem cases (14-50\%) [62]. Because histopathology of sarcoidosis and idiopathic granulomatous hypophysitis is identical, the latter can only be diagnosed after a sarcoid disease has been ruled out [3].

The human immunodeficiency virus (HIV) is the viral infection that most commonly leads to a pituitary inflammation in up to $23 \%$ of patients suffering from AIDS [63].

Any other viral inflammation of the brain can also lead to an inflammatory reaction of the pituitary gland [10]. In about 0.01 to $0.02 \%$ of patients with a herpes simplex infection, the virus enters the central nervous system via the olfactory bulb and causes a herpes simplex encephalitis. This leads to death in over $70 \%$ of untreated patients [64].

Pituitary inflammations due to bacterial infection are associated, for example, with the mycobacterium tuberculosis complex or the bacterium Treponema pallidum [10]. It is believed that the pituitary gland is involved in up to $49 \%$ of patients with tuberculosis [65]. In only one case of our collective the diagnosis was confirmed by autopsy. In the other three cases, tuberculosis was suspected. One patient was found to have tuberculous spondylitis at a later date. Nine cases of granulomatous inflammation were found in the group of probably primary hypophysitis. It cannot be ruled out that these cases could also be a reaction to a tuberculosis infection.

Correct classification of pituitary lesions is the key to proper treatment. For clinicians the diagnosis of hypophysitis after pituitary surgery may be unexpected. However, generally established therapy regimens for hypophysitis do not exist yet [34]. Therefore further interdisciplinary treatment should involve an endocrinologist, as was proposed for pituitary tumor centers [11], and a center-specific regimen should be established in any neurooncologic center.

Inflammation of the pituitary is an important differential diagnosis, requiring sophisticated histological examination. Since the incidence of such lesions is low, it seems to be advisable to involve a specialized pathology unit into the diagnostic work-up of such (unexpected) lesions. In Germany, this is facilitated by the pituitary tumor registry of the German Endocrinological Society (DGE). It should be noted that the histopathology of inflammation provides important information about its pathogenesis. Our study aims to provide a well substantiated insight into the different morphology of the inflammation. The proposed typing of inflammatory lesions on the one hand may help clinicians to understand the etiology of the inflammation in a given case and therefore direct to further diagnostic steps and patientspecific therapy. On the other hand it may enable further studies to establish generally accepted therapy regimen.

Acknowledgements The funding for the German Pituitary Tumor Registry to WS and RB from Novartis Pharma GmbH (Nuremberg, Germany), Novo Nordisk Pharma GmbH (Mainz, Germany), Pfizer Pharma GmbH (Berlin, Germany), and Ipsen Pharma GmbH (Ettlingen, Germany) is gratefully acknowledged. We thank all colleagues for sending tumor material to the German Pituitary Tumor Registry.

Author contribution JW: Archives, patient's files, statistics, DKL, JF, MB, RF, JKK, JK: Surgeries, RB, MG: Histopathology, immunocytochemistry, MB, FH: Histopathology (First histological diagnosis), WS: Histopathology, immunocytochemistry, conception.

Funding Open Access funding enabled and organized by Projekt DEAL. 


\section{Declarations}

Conflict of interest The authors declare that a conflict of interests does not exist.

Ethical approval All procedures performed in studies involving human participants were in accordance with the ethical standards of the institutional and/or national research committee and with the 1964 Helsinki declaration and its later amendments or comparable ethical standards (a separate ethic review and permission of a local committee was not necessary according to $\S 12$ to the Hamburgisches Krankenhausgesetz, Hamburg, Germany).

Open Access This article is licensed under a Creative Commons Attribution 4.0 International License, which permits use, sharing, adaptation, distribution and reproduction in any medium or format, as long as you give appropriate credit to the original author(s) and the source, provide a link to the Creative Commons licence, and indicate if changes were made. The images or other third party material in this article are included in the article's Creative Commons licence, unless indicated otherwise in a credit line to the material. If material is not included in the article's Creative Commons licence and your intended use is not permitted by statutory regulation or exceeds the permitted use, you will need to obtain permission directly from the copyright holder. To view a copy of this licence, visit http://creativecommons.org/licenses/by/4.0/.

\section{References}

1. Kleinschmidt-DeMasters BK, Lopes MB (2013) Update on hypophysitis and TTF-1 expressing sellar region masses. Brain Pathol 23:495-514

2. Saeger W, Moser R, Wernert N (1987) Inflammatory infiltrates in the hypophysis. Studies of a large autopsy sample. Pathologe 8:261-267

3. Saeger W (2016) Hypophysitis: types and differential diagnosis. Pathologe 37:230-237

4. Glezer A, Bronstein MD (2012) Pituitary autoimmune disease: nuances in clinical presentation. Endocrine 42:74-79

5. Bellastella G, Maiorino MI, Bizzarro A, Giugliano D, Esposito K, Bellastella A, De Bellis A (2016) Revisitation of autoimmune hypophysitis: knowledge and uncertainties on pathophysiological and clinical aspects. Pituitary 19:625-642

6. Yamamoto M, Iguchi G, Bando H, Kanie K, Hidaka-Takeno R, Fukuoka H, Takahashi Y (2020) Autoimmune pituitary disease: new concepts with clinical implications. Endocr Rev. https://doi. org/10.1210/endrev/bnz003

7. Caturegli P, Newschaffer C, Olivi A, Pomper MG, Burger PC, Rose NR (2005) Autoimmune hypophysitis. Endocr Rev 26:599-614

8. Gubbi S, Hannah-Shmouni F, Stratakis CA, Koch CA (2018) Primary hypophysitis and other autoimmune disorders of the sellar and suprasellar regions. Rev Endocr Metab Disord 19:335-347

9. Gutenberg A, Hans V, Puchner MJ, Kreutzer J, Bruck W, Caturegli P, Buchfelder M (2006) Primary hypophysitis: clinical-pathological correlations. Eur J Endocrinol 155:101-107

10. Prete A, Salvatori R (2000) Hypophysitis. In: Feingold KR, Anawalt B, Boyce A, Chrousos G, Dungan K, Grossman A, Hershman JM, Kaltsas G, Koch C, Kopp P, Korbonits M, McLachlan R, Morley JE, New M, Perreault L, Purnell J, Rebar R, Singer F, Trence DL, Vinik A, Wilson DP (eds) Endotext. South Dartmouth, MA
11. Casanueva FF, Barkan AL, Buchfelder M, Klibanski A, Laws ER, Loeffler JS, Melmed S, Mortini P, Wass J, Giustina A et al (2017) Criteria for the definition of Pituitary Tumor Centers of Excellence (PTCOE): a Pituitary Society Statement. Pituitary 20:489-498

12. Bernreuther C, Illies C, Flitsch J, Buchfelder M, Buslei R, Glatzel M, Saeger W (2017) IgG4-related hypophysitis is highly prevalent among cases of histologically confirmed hypophysitis. Brain Pathol 27:839-845

13. Honegger J, Fahlbusch R, Bornemann A, Hensen J, Buchfelder M, Muller M, Nomikos P (1997) Lymphocytic and granulomatous hypophysitis: experience with nine cases. Neurosurgery 40:713-722

14. Araujo PB, Coelho MC, Arruda M, Gadelha MR, Neto LV (2015) Ipilimumab-induced hypophysitis: review of the literature. J Endocrinol Invest 38:1159-1166

15. Tashiro T, Sano T, Xu B, Wakatsuki S, Kagawa N, Nishioka H, Yamada S, Kovacs K (2002) Spectrum of different types of hypophysitis: a clinicopathologic study of hypophysitis in 31 cases. Endocr Pathol 13:183-195

16. Buxton N, Robertson I (2001) Lymphocytic and granulocytic hypophysitis: a single centre experience. Br J Neurosurg $15: 242-245$

17. Bando H, Iguchi G, Fukuoka H, Taniguchi M, Yamamoto M, Matsumoto R, Suda K, Nishizawa H, Takahashi M, Kohmura E, Takahashi Y (2014) The prevalence of IgG4-related hypophysitis in 170 consecutive patients with hypopituitarism and/or central diabetes insipidus and review of the literature. Eur J Endocrinol 170:161-172

18. Caputo C, Bazargan A, McKelvie PA, Sutherland T, Su CS, Inder WJ (2014) Hypophysitis due to IgG4-related disease responding to treatment with azathioprine: an alternative to corticosteroid therapy. Pituitary 17:251-256

19. Hattori $Y$, Tahara S, Ishii $Y$, Kitamura T, Inomoto C, Osamura RY, Teramoto A, Morita A (2013) A case of IgG4-related hypophysitis without pituitary insufficiency. J Clin Endocrinol Metab 98:1808-1811

20. Hsing MT, Hsu HT, Cheng CY, Chen CM (2013) IgG4-related hypophysitis presenting as a pituitary adenoma with systemic disease. Asian J Surg 36:93-97

21. Leporati P, Landek-Salgado MA, Lupi I, Chiovato L, Caturegli P (2011) IgG4-related hypophysitis: a new addition to the hypophysitis spectrum. J Clin Endocrinol Metab 96:1971-1980

22. Ngaosuwan K, Trongwongsa T, Shuangshoti S (2015) Clinical course of IgG4-related hypophysitis presenting with focal seizure and relapsing lymphocytic hypophysitis. BMC Endocr Disord 15:64

23. Osawa S, Ogawa Y, Watanabe M, Tominaga T (2009) Hypophysitis presenting with atypical rapid deterioration: with special reference to immunoglobulin G4-related disease-case report. Neurol Med Chir (Tokyo) 49:622-625

24. Sosa GA, Bell S, Christiansen SB, Pietrani M, Glerean M, Loto M, Lovazzano S, Carrizo A, Ajler P, Fainstein Day P (2014) Histologically confirmed isolated IgG4-related hypophysitis: two case reports in young women. Endocrinol Diabetes Metab Case Rep 2014:140062

25. Tauziede-Espariat A, Polivka M, Bouazza S, Decq P, Robert G, Laloi-Michelin M, Adle-Biassette H (2015) The prevalence of IgG4-positive plasma cells in hypophysitis: a possible relationship to IgG4-related disease. Clin Neuropathol 34:181-192

26. Wong S, Lam WY, Wong WK, Lee KC (2007) Hypophysitis presented as inflammatory pseudotumor in immunoglobulin G4-related systemic disease. Hum Pathol 38:1720-1723

27. Ebbo M, Daniel L, Pavic M, Seve P, Hamidou M, Andres E, Burtey S, Chiche L, Serratrice J, Longy-Boursier M, Ruivard M, Haroche J, Godeau B, Beucher AB, Berthelot JM, Papo T, 
Pennaforte JL, Benyamine A, Jourde N, Landron C, Roblot P, Moranne O, Silvain C, Granel B, Bernard F, Veit V, Mazodier K, Bernit E, Rousset H, Boucraut J, Boffa JJ, Weiller PJ, Kaplanski G, Aucouturier P, Harle JR, Schleinitz N (2012) IgG4-related systemic disease: features and treatment response in a French cohort: results of a multicenter registry. Medicine (Baltimore) 91:49-56

28. Lin W, Lu S, Chen H, Wu Q, Fei Y, Li M, Zhang X, Tian X, Zheng W, Leng X, Xu D, Wang Q, Shen M, Wang L, Li J, Wu D, Zhao L, Wu C, Yang Y, Peng L, Zhou J, Wang Y, Sha Y, Huang X, Jiao Y, Zeng X, Shi Q, Li P, Zhang S, Hu C, Deng C, Li Y, Zhang S, Liu J, Su J, Hou Y, Jiang Y, You X, Zhang H, Yan L, Zhang W, Zhao Y, Zeng X, Zhang F, Lipsky PE (2015) Clinical characteristics of immunoglobulin G4-related disease: a prospective study of 118 Chinese patients. Rheumatology (Oxford) 54:1982-1990

29. Masaki Y, Dong L, Kurose N, Kitagawa K, Morikawa Y, Yamamoto M, Takahashi H, Shinomura Y, Imai K, Saeki T, Azumi A, Nakada S, Sugiyama E, Matsui S, Origuchi T, Nishiyama S, Nishimori I, Nojima T, Yamada K, Kawano M, Zen Y, Kaneko M, Miyazaki K, Tsubota K, Eguchi K, Tomoda K, Sawaki T, Kawanami T, Tanaka M, Fukushima T, Sugai S, Umehara H (2009) Proposal for a new clinical entity, IgG4-positive multiorgan lymphoproliferative syndrome: analysis of 64 cases of IgG4-related disorders. Ann Rheum Dis 68:1310-1315

30. Masaki Y, Kurose N, Yamamoto M, Takahashi H, Saeki T, Azumi A, Nakada S, Matsui S, Origuchi T, Nishiyama S, Yamada K, Kawano M, Hirabayashi A, Fujikawa K, Sugiura T, Horikoshi M, Umeda N, Minato H, Nakamura T, Iwao H, Nakajima A, Miki M, Sakai T, Sawaki T, Kawanami T, Fujita Y, Tanaka M, Fukushima T, Eguchi K, Sugai S, Umehara H (2012) Cutoff values of serum IgG4 and histopathological IgG4+ plasma cells for diagnosis of patients with IgG4-related disease. Int J Rheumatol 2012:580814

31. Takagi H, Iwama S, Sugimura Y, Takahashi Y, Oki Y, Akamizu T, Arima H (2020) Diagnosis and treatment of autoimmune and IgG4-related hypophysitis: clinical guidelines of the Japan Endocrine Society. Endocr J 67:373

32. Li Y, Gao H, Li Z, Zhang X, Ding Y, Li F (2019) Clinical Characteristics of 76 Patients with IgG4-Related Hypophysitis: A Systematic Literature Review. Int J Endocrinol 2019:5382640

33. Abe T, Matsumoto K, Sanno N, Osamura Y (1995) Lymphocytic hypophysitis: case report. Neurosurgery 36:1016-1019

34. Gazioglu N, Tuzgen S, Oz B, Kocer N, Kafadar A, Akar Z, Kuday $\mathrm{C}$ (2000) Idiopathic granulomatous hypophysitis: are there reliable, constant radiological and clinical diagnostic criterias? Neuroradiology 42:890-894

35. Honegger J, Schlaffer S, Menzel C, Droste M, Werner S, Elbelt U, Strasburger C, Stormann S, Kuppers A, van der Werf CS, Deutschbein T, Stieg M, Rotermund R, Milian M, Petersenn S, Pituitary E et al (2015) Diagnosis of primary hypophysitis in Germany. J Clin Endocrinol Metab 100:3841-3849

36. Hunn BH, Martin WG, McLean CA (2014) Idiopathic granulomatous hypophysitis: comments and a disease registry. J Clin Neurosci 21:891

37. Leung GK, Lopes MB, Thorner MO, Vance ML, Laws ER Jr (2004) Primary hypophysitis: a single-center experience in 16 cases. J Neurosurg 101:262-271

38. Teramoto A, Hirakawa K, Sanno N, Osamura Y (1994) Incidental pituitary lesions in 1,000 unselected autopsy specimens. Radiology 193:161-164

39. Benveniste RJ, King WA, Walsh J, Lee JS, Naidich TP, Post KD (2004) Surgery for Rathke cleft cysts: technical considerations and outcomes. J Neurosurg 101:577-584

40. Kuan EC, Yoo F, Chyu J, Bergsneider M, Wang MB (2017) Treatment outcomes of Rathke's Cleft cysts managed with marsupialization. J Neurol Surg B Skull Base 78:112-115
41. Wang S, Nie Q, Wu Z, Zhang J, Wei L (2020) MRI and pathological features of Rathke cleft cysts in the sellar region. Exp Ther Med 19:611-618

42. Hama S, Arita K, Nishisaka T, Fukuhara T, Tominaga A, Sugiyama K, Yoshioka H, Eguchi K, Sumida M, Heike Y, Kurisu K (2002) Changes in the epithelium of Rathke cleft cyst associated with inflammation. J Neurosurg 96:209-216

43. El Malik EFB, Manoranjan B, Ajani O, Zidan A (2018) Hypophysitis due to paranasal sinusitis: neurosurgical perspective from developing world. World Neurosurg 115:162-165

44. Naama O, Gazzaz M, Boulahroud O, Elmoustarchid B (2014) Infection of a Rathke cleft cyst: a rare cause of pituitary abscess. Surg Infect (Larchmt) 15:358-360

45. Furnica RM, Lelotte J, Duprez T, Maiter D, Alexopoulou O (2018) Recurrent pituitary abscess: case report and review of the literature. Endocrinol Diabetes Metab Case Rep. https://doi.org/10. 1530/EDM-17-0162

46. Vates GE, Berger MS, Wilson CB (2001) Diagnosis and management of pituitary abscess: a review of twenty-four cases. J Neurosurg 95:233-241

47. Montrieul B, Janny P, Pignide L, Chabannes J (1965) Observations on hypophyseal abscesses. Neurochirurgie 11:366-371

48. Domingue JN, Wilson CB (1977) Pituitary abscesses. Report of seven cases and review of the literature. J Neurosurg 46:601-608

49. Gao L, Guo X, Tian R, Wang Q, Feng M, Bao X, Deng K, Yao Y, Lian W, Wang R, Xing B (2017) Pituitary abscess: clinical manifestations, diagnosis and treatment of 66 cases from a large pituitary center over 23 years. Pituitary 20:189-194

50. Liu F, Li G, Yao Y, Yang Y, Ma W, Li Y, Chen G, Wang R (2011) Diagnosis and management of pituitary abscess: experiences from 33 cases. Clin Endocrinol (Oxf) 74:79-88

51. Sautner D, Saeger W, Ludecke DK, Jansen V, Puchner MJ (1995) Hypophysitis in surgical and autoptical specimens. Acta Neuropathol 90:637-644

52. Holck S, Laursen H (1983) Prolactinoma coexistent with granulomatous hypophysitis. Acta Neuropathol 61:253-257

53. Mitra S, Chakraborty H (2017) Intratumoral granulomatous reaction in recurrent pituitary adenoma: a unique presentation. J Cancer Res Ther 13:580-582

54. Sivakoti S, Nandeesh BN, Bhatt AS, Chandramouli BA (2019) Pituitary adenoma with granulomatous hypophysitis: a rare coexistence. Indian J Endocrinol Metab 23:498-500

55. Osamura RY, Lopes MBS, Grossman A, Kontogeorgos G, Trouillas J (2017) WHO classification of tumours of the pituitary. WHO Classifi Tumours Endocrine Organs 4:11-63

56. Bettendorf M, Fehn M, Grulich-Henn J, Selle B, Darge K, Ludecke DK, Heinrich UE, Saeger W (1999) Lymphocytic hypophysitis with central diabetes insipidus and consequent panhypopituitarism preceding a multifocal, intracranial germinoma in a prepubertal girl. Eur J Pediatr 158:288-292

57. Fehn M, Bettendorf M, Ludecke DK, Sommer C, Saeger W (1999) Lymphocytic hypophysitis masking a suprasellar germinoma in a 12-year-old girl-a case report. Pituitary 1:303-307

58. Deodhare SS, Bilbao JM, Kovacs K, Horvath E, Nomikos P, Buchfelder M, Reschke K, Lehnert H (1999) Xanthomatous hypophysitis: a novel entity of obscure etiology. Endocr Pathol 10:237-241

59. Folkerth RD, Price DL Jr, Schwartz M, Black PM, De Girolami U (1998) Xanthomatous hypophysitis. Am J Surg Pathol 22:736-741

60. Amano K, Kubo O, Komori T, Tanaka M, Kawamata T, Hori T, Okada Y (2013) Clinicopathological features of sellar region xanthogranuloma: correlation with Rathke's cleft cyst. Brain Tumor Pathol 30:233-241

61. Hagerstrand I, Linell F (1964) The prevalence of sarcoidosis in the autopsy material from a Swedish town. Acta Med Scand Suppl 425:171-174 
62. Anthony J, Esper GJ, Ioachimescu A (2016) Hypothalamic-pituitary sarcoidosis with vision loss and hypopituitarism: case series and literature review. Pituitary 19:19-29

63. Ferreiro J, Vinters HV (1988) Pathology of the pituitary gland in patients with the acquired immune deficiency syndrome (AIDS). Pathology 20:211-215

64. Zhang SY (2020) Herpes simplex virus encephalitis of childhood: inborn errors of central nervous system cell-intrinsic immunity. Hum Genet 139:911-918
65. Dhanwal DK, Vyas A, Sharma A, Saxena A (2010) Hypothalamic pituitary abnormalities in tubercular meningitis at the time of diagnosis. Pituitary 13:304-310

Publisher's Note Springer Nature remains neutral with regard to jurisdictional claims in published maps and institutional affiliations. 